\title{
VISIT TO THE MUSEUM OF PRACTICAL GEOLOGY.
}

\author{
S \\ (Demonatbation on the Rock Colleotion.) \\ Director :-Frank Ruthey, Esq., F.G.S.
}

The arrangement in this collection, as pointed out by the Director, is stratigraphical as well as topographical, and in no way based on mineral constitution. The eruptive rocks will eventually be distinguished by red labels.

Particular attention was drawn to the rocks of the Lake District (Silurian). The micaceous dykes of portions of this country are noteworthy. The chiastolite slate which intervenes between the granite and the ordinary Skiddaw slate was pointed out. An extensive series of lavas, frequently containing very fresh augite, together with triclinic felspar and orthoclase, holds a position intermediate between the dolerites and the trachytes. Here also is observed a large series of fragmental volcanic rocks--some undoubtedly ashes, and others whose origin is not so obvious.

Amongst Devonian rocks, as developed in England, were shown basaltic lavas from the neighbourhood of Tavistock, and specimens of the Brent Tor lavas, breccias, and volcanic bombs. Allusion was also made to the extensive decomposition and replacement of matter in the schistose ashes of this region. The Dunstones of Devon are represented by old lavas and schistose tuffs. The remainder of the rock collection is arranged stratigraphically, but there is a case reserved to illustrate the general principles of petrographical science.

The Director afterwards proceeded to describe the method of preparing sections of rocks for microscopic examination, and subsequently indicated, with the aid of diagrams and drawings on the black board, some of the means for the determination of the minerals by optical characters. He more especially dwelt on the phenomena of polarization, on the methods of determining the optic axes in crystals, and on the measurement of angles of "extinction" as a means for determining the species in, for instance, the several triclinic felspars. The minute structure of vitreous rocks was next described, and the numerous changes set up in natural glasses, whereby they become opaque and stony. 
In conclusion the Director gave explanations with regard to the names of several rocks, such as Diabase, Felstone, \&c., and offered the subjoined Table of Classification of the chief Eruptive Rocks for consideration :-

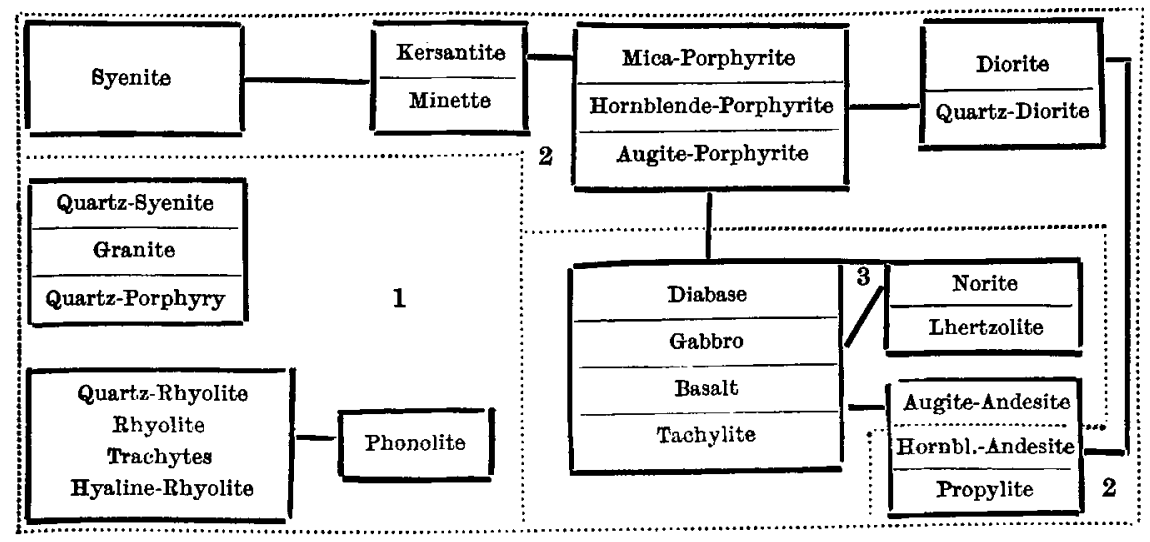

ORDINARY MEETING.

April 1st, 1881.

W. H. Hodlegton, Esq., M.A., F.G.S., \&c., President, in the chair.

The Donations to the Library were announced as usual, and the donors thanked.

The following were elected members of the Association :-

J. Knight, Esq., M.A., F.G.S.; Herbert Roper, Esq.; Reuben C. Green, Esq., and Capt. Underwood.

The following papers were read:-

1. "Notes on a Mandible of Ischyodus Townsendii, found at Upway, Dorsetshire, in the Portland Oolite." By E. T. Newton, Esq., F.G.S.

2. "A Geological Trip to Colorado in 1880." By S. R. Pattison, Esq., F.G.S. 